INTERNATIONAL FOOD POLICY

RESEARCH INSTITUTE

sustainable solutions for ending hunger and poverty

A member of the CGIAR consortium

IFPRI Discussion Paper 01241

January 2013

\title{
A Global Assessment of the Economic Effects of Export Taxes
}

\author{
David Laborde \\ Carmen Estrades \\ Antoine Bouët
}

Markets, Trade and Institutions Division 


\section{INTERNATIONAL FOOD POLICY RESEARCH INSTITUTE}

The International Food Policy Research Institute (IFPRI) was established in 1975 to identify and analyze national and international strategies and policies for meeting the food needs of the developing world on a sustainable basis, with particular emphasis on low-income countries and on the poorer groups in those countries. IFPRI is a member of the CGIAR Consortium.

\section{PARTNERS AND CONTRIBUTORS}

IFPRI gratefully acknowledges the generous unrestricted funding from Australia, Canada, China, Denmark, Finland, France, Germany, India, Ireland, Italy, Japan, the Netherlands, Norway, the Philippines, South Africa, Sweden, Switzerland, the United Kingdom, the United States, and the World Bank.

\section{AUTHORS}

David Laborde, International Food Policy Research Institute Senior Research Fellow, Markets, Trade and Institutions Division d.laborde@cgiar.org

\section{Carmen Estrades, International Food Policy Research Institute} Postdoctoral Fellow, Markets, Trade and Institutions Division

Antoine Bouët, International Food Policy Research Institute

Senior Research Fellow, Markets, Trade and Institutions Division Université Montesquieu Bordeaux IV

Professor of Economics, Laboratoire d'Analyse et de Recherche en Économie et Finance Internationales

\section{Notices}

IFPRI Discussion Papers contain preliminary material and research results. They have been peer reviewed, but have not been subject to a formal external review via IFPRI's Publications Review Committee. They are circulated in order to stimulate discussion and critical comment; any opinions expressed are those of the author(s) and do not necessarily reflect the policies or opinions of IFPRI.

Copyright 2013 International Food Policy Research Institute. All rights reserved. Sections of this material may be reproduced for personal and not-for-profit use without the express written permission of but with acknowledgment to IFPRI. To reproduce the material contained herein for profit or commercial use requires express written permission. To obtain permission, contact the Communications Division at ifpri-copyright@cgiar.org. 


\section{Contents}

Abstract $\quad$ V

1. Introduction 1

2. Methodology 3

3. Results 27

4. Concluding Remarks

Appendix : Supplementary Tables $\quad 38$

$\begin{array}{ll}\text { References } & 40\end{array}$ 


\section{Tables}

2.1-Export taxes in the GTAP7.1 database: Sectoral analysis 3

2.2-Export taxes in the GTAP7.1 database: Country analysis 4

2.3-Average export taxes (percent), by sector $\quad 6$

2.4-Average export taxes (percent), top 20 countries 23

$3.1-$ Global and regional effects of export tax removal, 2020

3.2-Changes in global trade: Sectoral results (in 2020 compared with the baseline) 34

3.3- Sensitivity analysis on global and regional effects of export tax removal on real income and export volume 36

A.1-Geographical aggregation and GTAP correspondence $\quad 38$

A.2-Sectoral aggregation and GTAP correspondence $\quad 39$

\section{Figures}

3.1 -Top price reductions, world (FOB) 28

3.2-Percentage changes in sectoral value-added by group of countries (in 2020 compared with the $\begin{array}{ll}\text { baseline) } & 30\end{array}$

3.3-Decomposition in the changes of real income by activity 31

3.4-Decomposition in the changes of export volume by activity 32

3.5-Decomposition in the changes of government income from trade taxes, by activity 33

3.6-Comparing elimination of tariff export restrictions and import restrictions 34 


\begin{abstract}
This study has been undertaken to understand and evaluate the potential negative consequences of export taxes which are implemented by many countries today and which are not disciplined by any international agreement. This paper uses a new detailed global dataset on export taxes at the HS6 (Harmonized System 6 level) level and the MIRAGE (Modeling International Relationships in Applied General Equilibrium) global computable general equilibrium model to assess the impact of export taxes on the world economy. We find that limitations on export taxes would have worldwide effects: the average export tax on global merchandise trade was 0.48 percent in 2007 , with the bulk of these taxes imposed on energy products. The removal of these taxes would increase global welfare by 0.23 percent, which is a larger figure than the expected gains from the World Trade Organization's Doha Development Round. Both developed and emerging economies, such as China and India, would gain from such policies, even if they currently impose export taxes. Medium and small food-importing countries without market power (such as the least-developed countries) would also benefit from the elimination of export restrictions, especially during food crisis situations. Both the energy sector and the export taxes implemented by Commonwealth of Independent States countries appear to play a critical role in the overall economic impact of such a policy change. However, the fact that some countries, such as Argentina, would experience income losses due to such a policy change is a major challenge to overall positive reform in this area.
\end{abstract}

\title{
Keywords: export tax, computable general equilibrium models
}





\section{INTRODUCTION}

International trade negotiations have been largely driven by mercantilist interests that view imports as a threat and exports as an opportunity. As a result, policymakers and negotiators have focused on making concessions aimed at trade market access (such as reductions in import duties) and on ensuring fair competition (for example establishing disciplines on production and export subsidies). Therefore, even though many countries use export taxes and export restrictions (in 2004, Piermartini noted that approximately one-third of World Trade Organization members imposed export duties), policymakers, trade negotiators, 1 and economists have given these policies much less attention.

However, the effects of export taxes are numerous. These taxes are popular in many countries, in part because of the terms of trade effect (that is, the market power of key suppliers), the consumer price (food security) or intermediate input price (industrial policy in favor of processed goods) reduction and stabilization effects, the positive impact on government revenue, and the income redistribution effect. However, these taxes can also create serious negative externalities for trade partners. Recent years have been marked by a renewal of interest in this issue from the trade community. The 2007-08 food price crisis shed light on export policies' dangerous consequences for food security during periods of price spikes (Anderson and Martin 2011; Bouët and Laborde 2011). The imposition of export restrictions on key inputs, such as rare earths, has also led to a trade dispute between the European Union and China (see the U.S. Trade Representative's website ${ }^{2}$ ).

Although export taxes are an important concern in the international trade arena, to the best of our knowledge, no study has assessed their importance at the global level and evaluated their potential impact on world trade and welfare. Existing assessments of the potential impact of export taxes are focused on specific sectors and may use general equilibrium models (Warr 2001, on rice) or partial equilibrium models (Turner et al. 2008, on roundwood). Yet these sectors are of minor importance, and such partial equilibrium analyses do not take into account how changes in prices and output in one sector might affect other sectors (and, therefore, further affect welfare indirectly). This paper, which uses a new dataset on export taxes applied globally in all sectors and MIRAGE (a multisectoral, multiregional, and dynamic computable general equilibrium model), intends to fill this gap. It provides a global measure of the worldwide importance of export taxes in 2007 and studies how the global removal of export taxes would affect global trade and the real income of major trading blocks.

The limited analysis of export taxation under a global and multisectoral framework is largely due to a lack of data. In recent years, the Market Access Map HS6 (MAcMapHS6) and Global Trade Analysis Project (GTAP) databases have made detailed information on applied tariffs accessible for researchers and practitioners. ${ }^{3}$ Unfortunately, such detailed information (taxes at a bilateral level at the HS6 level) does not yet exist for export taxes. International institutions do not provide systematic datasets on this issue, and World Trade Organization (WTO) notifications remain scarce. For the purposes of this paper, we partially overcome this problem by building a worldwide database of export taxes at the HS6-digit level.

Our main results show the following: First, the average export tax on global merchandise trade was 0.48 percent in 2007. Export taxes concentrate on raw agricultural products (raw hides, oilseeds,

\footnotetext{
${ }^{1}$ The World Trade Organization (WTO) does not prohibit export taxes and other forms of export restrictions. More precisely, as stated by Crosby (2008, p. 3), "General WTO rules do not discipline Members' application of export taxes," but "they can agree - and several recently acceded countries, including China, have agreed — to legally binding commitments in this regard." In addition, the Uruguay Round Agreement on Agriculture stipulates that when implementing a new export restriction, a WTO member must (1) consider the implications of these policies on food security in importing countries, (2) give notice to WTO the Committee on Agriculture, and (3) consult with WTO members that have an interest. This agreement does not institute any penalty for countries ignoring the rules.

${ }^{2} \mathrm{http}: / /$ www.ustr.gov/about-us/press-office/press-releases/2012/march/united-states-challenges-china $\%$ E2\%80\%99s-exportrestraints-r

${ }^{3}$ For the latest version of MAcMapHS6, see Boumellassa, Laborde, and Mitaritonna (2009). For more information on the latest version of the GTAP database, see Narayanan and Walmsley (2008).
} 
cotton, and cocoa), minerals, processed oilseeds (soybean oil and palm oil), aluminum and iron (scraps and semiprocessed), and timber (rough and logs), with the bulk of these taxes imposed on energy products. The export tax level applied by Russia on natural gas is the main source of global distortion. Second, an export tax removal leads to an overall gain of 0.24 percent in world real income, or US\$133 billion per year by 2020, and expands world trade volumes by 2.8 percent as compared with their 2020 levels in the baseline. Large real income gains $(+1.6$ percent $)$ are concentrated in oil-exporting countries. Our analysis has its limitations, however. First, it only focuses on export taxes, which is a subset of total export restrictions driven by methodological and data availability constraints. Therefore, the assessment should not be considered exhaustive in that it does not provide a full account of the economic effect of all export restrictions that are currently in place across the global economy. Second, since the scope of this exercise involves a wide range of situations regarding export tax policies, we operate in a simplified framework. We consider export taxes to be fixed and removed exogenously, independently of the level of world prices and the actions performed by other countries. By doing so, we eliminate strategic interactions. In addition, we assume that firms operate in perfect competition.

The main implications of our assumptions are as follows: First, in reality, if governments were to remove all export taxes simultaneously, there would likely be other factors at play (such as reciprocal concessions from other countries for countries that have initially high export taxes or the existence of low world prices for certain commodities that render export restraints ineffective). Such factors would also have an impact on the measures examined here (that is, welfare, trade volumes, prices, and so on). In our model, however, we simply force all export taxes to be removed, regardless of whether a government would endogenously choose to do so. Second, the assumption of perfect competition implies that all producers will price their goods at marginal cost and cannot manipulate prices by restricting output. ${ }^{4}$

In Section 2, we present the methodology, assumptions, and data sources used for building this database, which, in spite of its limitations, is the first of its kind. Section 2 also presents the main features of the MIRAGE model applied in this paper. In Section 3, we analyze the effects of worldwide elimination of export taxes on trade and welfare and compare these effects with those of an elimination of import tariffs in order to assess the relative impact of each type of policy. Finally, Section 4 concludes.

\footnotetext{
${ }^{4}$ Bouët and Laborde (2011) discussed the strategic interactions of exporters and importers, focusing on the wheat sector and raising the issue of export restrictions in the context of food crisis. They showed that export taxes are a typical example of a "beggar thy neighbor" policy — that is, export taxes may be considered a rational decision from a single country's point of view in the sense that domestic prices may remain constant thanks to an export tax, but this policy amplifies the negative aspects of the initial shock for other countries because it leads to further increases in international prices. To reach these conclusions, the authors applied a global CGE model (MIRAGE) but only focused on one sector (wheat).
} 


\section{METHODOLOGY}

\section{Dataset}

There is no comprehensive dataset of export taxes applied worldwide. Table 2.1 and Table 2.2 present the export tax structure from the GTAP dataset, which, in spite of being the most complete existing database for trade analysis purposes, has a limited export tax coverage: only 21 sectors out of 42 (trade in merchandise) have observations with export taxes, and, on average, 17 percent of the exporters of these sectors use export taxes. Overall, the estimated average export tax on global trade in goods is 0.5 percent. Commonwealth of Independent States (CIS) countries, led by Russia, as well as Association of Southeast Nations (ASEAN) members (for example, the Philippines and Indonesia) and Pakistan, use these tools the most, whereas other countries (for example, Argentina and Brazil) also rely on export taxes.

Table 2.1-Export taxes in the GTAP7.1 database: Sectoral analysis

\begin{tabular}{lccc}
\hline GTAP Sector & $\begin{array}{c}\text { Number of } \\
\text { Countries } \\
\text { using Export } \\
\text { Taxes }\end{array}$ & $\begin{array}{c}\text { Frequency: } \\
\text { Number of Export } \\
\text { Tax Cases/Number } \\
\text { of Exporters } \\
\text { (percent) }\end{array}$ & $\begin{array}{c}\text { Global } \\
\text { Average } \\
\text { Export Tax } \\
\text { (percent) }\end{array}$ \\
\hline Raw milk & 8 & 9.0 & 1.0 \\
Coal, natural & 9 & 10.0 & 0.0 \\
Oil & 15 & 17.0 & 4.0 \\
Gas & 26 & 43.0 & 24.0 \\
Minerals (nec) & 14 & 13.0 & 0.0 \\
Textiles & 17 & 15.0 & 1.0 \\
Wearing, apparel & 14 & 13.0 & 5.0 \\
Leather products & 11 & 10.0 & 0.0 \\
Wood products & 16 & 14.0 & 0.0 \\
Paper products, publishing & 17 & 15.0 & 0.0 \\
Petroleum and coal products & 17 & 15.0 & 2.0 \\
Chemicals, rubber and plastic & 20 & 18.0 & 0.0 \\
products & 16 & 14.0 & 0.0 \\
Mineral products (nec) & 17 & 15.0 & 0.0 \\
Ferrous metals & 16 & 14.0 & 0.0 \\
Metals (nec) & 20 & 18.0 & 0.0 \\
Metal products & 26 & 23.0 & 0.0 \\
Motor vehicles and parts & 43 & 38.0 & 0.0 \\
Transport equipment (nec) & 17 & 15.0 & 0.0 \\
Electronic equipment & 34 & 30.0 & 0.0 \\
Machinery and equipment (nec) & 23 & 21.0 & 0.0 \\
Manufactures (nec) & 17.0 & \\
\hline Soure: Auts & 17.0 & & 0.0 \\
\hline
\end{tabular}

Source: Authors' computations based on the GTAP 7.1 release.

Note: $\quad$ nec $=$ not elsewhere classified. 
Table 2.2-Export taxes in the GTAP7.1 database: Country analysis

\begin{tabular}{lcc}
\hline GTAP Region & $\begin{array}{l}\text { Number of GTAP } \\
\text { Sectors with Export } \\
\text { Taxes }\end{array}$ & $\begin{array}{c}\text { Average Export } \\
\text { Taxes on Total } \\
\text { Exports (percent) }\end{array}$ \\
\hline Russia & 21 & 24.7 \\
New Zealand & 19 & 0.3 \\
Belorussia & 19 & 7.4 \\
Indonesia & 17 & 0.8 \\
Kyrgyzstan & 17 & 1.8 \\
Rest of CIS & 17 & 2.8 \\
Nigeria & 17 & 0.4 \\
Pakistan & 15 & 1.5 \\
Ukraine & 15 & 0.4 \\
Philippines & 14 & 1.1 \\
Rest of Europe & 14 & 0.3 \\
Rest of West Africa & 13 & 0.6 \\
South Africa & 13 & 1.1 \\
Panama & 11 & 0.1 \\
Laos & 9 & 0.1 \\
Argentina & 9 & 0.3 \\
Venezuela & 8 & 0.1 \\
Sri Lanka & 7 & 0.3 \\
Brazil & 7 & 0.2 \\
Senegal & 7 & 0.2 \\
Australia & 6 & 0.4 \\
\hline Soure: Aut & 17 & \\
\hline
\end{tabular}

Source: Authors' computations based on the GTAP 7.1 release.

Note: $\quad$ nec $=$ not elsewhere classified.

The data in Tables 2.1 and 2.2 have several flaws. First, they are not based on data collection at the HS level; instead, they result from the processing of macrodata from social accounting matrixes. The data can be outdated and may mix export taxes and other price distortions between domestic and export prices. In some cases, the data are defined at a higher level of aggregation and are then spread out over several GTAP sectors during the GTAP database formatting process. Second, the GTAP treatment on agricultural products leads only to a net distortion at the border: net export taxes from export subsidies. Since agricultural negotiations have not focused on export subsidies, the GTAP database has discarded the information on export taxes for agricultural products. This result is clearly illustrated in Table 2.1, in which no export taxes are applied to agricultural trade. Only the "raw milk" sector (rmk) is affected, though in reality, there is almost no international trade of this commodity. Third, it is obvious that some important countries, such as China, are missing from the list of export tax users. Fourth, because the GTAP database has a specific module that addresses the energy sectors (coal, gas, oil, petroleum, and coal, either processed or refined), there is a higher concentration of export taxes in the energy sector due to the different treatment of and additional information available for that sector.

To overcome these limitations, we have developed a new database defined at the exporter/HS6 level, with information on ad valorem and specific export taxes. This dataset is then aggregated into the GTAP database nomenclature; we rebalance the GTAP database before feeding values into the model. 
The overall approach closely resembles the methodology used in the MAcMapHS6 import duties dataset and its linkage with the GTAP database (see Boumellassa, Laborde, and Mitaritonna 2009).

The most important technical choices for building the database are the following:

- Due to poor information and implementation challenges, we do not consider bilateral export taxes (no preferential treatment).

- We try to keep the most recent information, particularly the data on export taxes provided by the Directorate General for Trade of the European Union Commission, but we supplement this with alternative sources, such as trade policy reviews by the WTO, the Organization for Economic Cooperation and Development (OECD), DG Trade - EU trade briefs, and publisher resources (Piermartini 2004; Bouët and Laborde 2010). However, any short-term, ongoing measures are discarded.

- We use the MAcMApHS6 trade weights to aggregate export taxes from the HS6 level to the GTAP sectors. However, we take into consideration the fact that the FOB (Free On Board) value includes the export taxes, and we compute pre-export tax weights before aggregating.

- For energy sectors, we keep the existing GTAP7 export taxes information when available. ${ }^{5}$

These changes do not greatly modify the average global level of export taxes: the average export tax on global merchandise trade is 0.48 percent (compared with a 0.50 percent average export tax on global trade in goods in the GTAP7 database). However, they do lead to strong sectoral and country reallocation - for example, China now applies export taxes, Argentina jumps from an average 0.3 percent export tax to more than 9 percent, and export taxes disappear from the apparel sector and concentrate instead on raw agricultural products (raw hides, oilseeds, cotton, and cocoa), minerals, processed oilseeds (soybean oil and palm oil), aluminum and iron (scraps and semiprocessed), and timber (rough and logs). The bulk of export taxes are still imposed on energy products, and the export tax level applied by Russia on natural gas (of which source is GTAP) is the main source of global distortion. The largest average export taxes by sector and exporter are provided in Tables 2.3 and 2.4. It appears that aside from the natural gas sector, the two most distorted sectors are forestry and vegetable oils.

\footnotetext{
${ }^{5}$ We should keep in mind that in the GTAP database, the export tax on an energy product, such as natural gas, is equal to the price distortion between domestic prices and export prices. This difference can be the result of different policies, such as explicit tax, export constraint/restriction, or strategic behavior.
} 
Table 2.3-Average export taxes (percent), by sector

\begin{tabular}{llc}
\hline $\begin{array}{l}\text { Code Sector } \\
\text { GTAP7 }\end{array}$ & Sector & $\begin{array}{l}\text { Trade- } \\
\text { Weighted } \\
\text { Export Tax }\end{array}$ \\
\hline GAS & Gas & 24.1 \\
FRS & Forestry & 8.9 \\
VOL & Vegetable oils and fats & 5.7 \\
OIL & Oil & 3.9 \\
CMT & Bovine meat products & 2.3 \\
OSD & Oilseeds & 2.0 \\
P_C & Petroleum, coal products & 1.8 \\
OCR & Crops (nec) & 1.7 \\
GRO & Cereal grains (nec) & 1.3 \\
WHT & Wheat & 1.3 \\
OMN & Minerals (nec) & 0.8 \\
LUM & Wood products & 0.5 \\
NFM & Metals (nec) & 0.3 \\
CTL & Bovine cattle, sheep and & 0.3 \\
PFB & goats, horses & 0.2 \\
PDR & Plant-based fibers & 0.2 \\
LEA & Paddy rice & 0.2 \\
WOL & Leather products & 0.2 \\
COA & Wool, silkworm cocoons & 0.2 \\
V_F & Coal & 0.1 \\
\hline SOHE: & Vegetables, fruit, nuts & \\
\hline
\end{tabular}

Source: Authors' computation.

Note: nec $=$ not elsewhere classified. 
Table 2.4-Average export taxes (percent), top 20 countries

\begin{tabular}{llc}
\hline $\begin{array}{l}\text { Code Country } \\
\text { GTAP7 }\end{array}$ & Country & $\begin{array}{l}\text { Trade- } \\
\text { Weighted } \\
\text { Export Tax }\end{array}$ \\
\hline RUS & Russian Federation & 23.1 \\
ARG & Argentina & 9.1 \\
XWF & Rest of Western Africa & 4.3 \\
XNF & Rest of North Africa & 3.8 \\
BLR & Belarus & 2.0 \\
XSU & Rest of Former Soviet Union & 1.9 \\
XOC & Rest of Oceania & 1.6 \\
XCF & Rest of Central Africa & 1.3 \\
IDN & Indonesia & 1.0 \\
BOL & Bolivia & 1.0 \\
LAO & Lao People's Democratic & 0.8 \\
& Republic & \\
XSC & Rest of South African Customs & 0.7 \\
AUS & Union & 0.6 \\
IND & Australia & 0.5 \\
UGA & India & 0.5 \\
ZAF & Uganda & 0.4 \\
MOZ & South Africa & 0.4 \\
NOR & Mozambique & 0.4 \\
MAR & Norway & 0.4 \\
MYS & Morocco & 0.3 \\
\hline Soraysia & Malay & \\
\hline
\end{tabular}

Source: Authors' computation.

\section{The MIRAGE Global Computable General Equilibrium Model}

This section summarizes the features of the MIRAGE version used in this study and the key assumptions relevant for this paper.

\section{General Features}

MIRAGE is a multisectoral, multiregional computable general equilibrium (CGE) model devoted to trade policy analysis. ${ }^{6}$ The model operates in a sequential dynamic recursive setup - that is, it is solved for one period, and then all variable values, determined at the end of a period, are used as the initial values of the next period. Macroeconomic data and social accounting matrixes, in particular, come from the GTAP7 database, which describes the world economy in 2004 (Narayanan and Walmsley 2008). From the supply side in each sector, the production function is a Leontief function of value-added and intermediate inputs: for its production, one output unit needs $x$ percent of an aggregate of productive factors (labor, unskilled and skilled; capital; land and natural resources) and $(1-x)$ percent of intermediate inputs. The intermediate inputs function is an aggregate constant elasticity of substitution (CES) function of all goods, which means that substitutability exists between two intermediate goods, depending on the relative prices

\footnotetext{
${ }^{6}$ For more information on MIRAGE, see the MIRAGE wiki-site at http://mirage.cepii.free.fr/miragewiki.
} 
of these goods. This substitutability is constant and at the same level for any pair of intermediate goods. Similarly, in the generic version of the model, value-added is a CES function of unskilled labor, land, natural resources, and a bundle of skilled labor and capital. This nesting allows the modeler to introduce less substitutability between capital and skilled labor than between these two and other factors. In other words, when the relative price of unskilled labor is increased, this factor is replaced by a combination of capital and skilled labor, which are more complementary. ${ }^{7}$

Factor endowments are fully employed. The only factor with constant supply is natural resources, with a few exceptions detailed later in this paper. Capital supply is modified each period because of depreciation and investment. Growth rates of labor supply are fixed exogenously. Land supply is endogenous, as it depends on the real remuneration of land. In some countries (such as Japan and the European Union), land is a scarce factor, such that elasticity of supply is low. In others (such as Argentina, Australia, and Brazil), land is abundant, and elasticity is high.

Skilled labor is the only factor that is perfectly mobile. Installed capital and natural resources are sector specific. New capital is allocated among sectors according to an investment function. Unskilled labor is imperfectly mobile between agricultural and nonagricultural sectors, according to a constant elasticity of transformation (CET) function, because unskilled labor's remuneration in agricultural activities is different from that in nonagricultural activities. This factor is allocated between these two series of sectors according to the ratio of remunerations. Land is also imperfectly mobile between agricultural sectors.

The MIRAGE model uses full employment of labor; more precisely, there is a constant aggregate employment (wage flexibility) in all countries. It is quite possible to suppose that total aggregate employment is variable and that there is unemployment; however, this choice greatly increases the complexity of the model, which means simplifying assumptions have to be made in other areas (such as in the number of countries or sectors). This assumption could amplify the benefits of trade liberalization for developing countries. In full-employment models, increased demand for labor (from increased activity and exports) leads to higher real wages, such that the origin of comparative advantage is progressively eroded; however, in models with unemployment, real wages are constant, and exports increase much more.

Capital in a given region, whatever its origin (domestic or foreign), is assumed to be obtained by assembling intermediate inputs according to a specific combination. The capital good is the same whatever the sector. In this version of MIRAGE, we assume that all sectors operate under perfect competition, there are no fixed costs, and price equals marginal cost.

The demand side is modeled in each region through a representative agent whose propensity to save is constant. The rest of the national income is used to purchase final consumption. Preferences between sectors are represented by a linear expenditure system-constant elasticity of substitution (LESCES) function. This implies that consumption has a nonunitary income elasticity - that is, when the consumer's income is augmented by $x$ percent, the consumption of each good is not systematically raised by $x$ percent, other things being equal. The sector subutility function used in MIRAGE is a nesting of four CES-Armington functions that defines the origin of the goods. In this study, Armington elasticities are drawn from the GTAP7 database and are assumed to be the same across regions.

Macroeconomic closure is obtained by assuming that the sum of the balance of goods and services and foreign direct investment (FDI) is constant. It implies an adjustment of the real exchange rate to keep this balance constant. Moreover a lump-sum tax is perceived in each country in order to keep public revenues constant (where export taxes are removed).

\footnotetext{
${ }^{7}$ In the generic version, substitution elasticity among unskilled labor, land, natural resources, and the bundle of capital and skilled labor is 1.1 for all sectors except for agriculture and mining, where it is equal to 0.2 ; it is only 0.6 between capital and skilled labor.
} 


\section{Key Assumptions}

This section addresses a few methodological points concerning the focus of this paper. First, we consider export taxes to be exogenous policy instruments: they are not determined by optimal behavior from policymakers and do not respond to foreign policies and changes in world prices. This implies that export taxes do not change in the baseline; thus, we remove them exogenously in the policy scenarios. Because we look at a global export tax elimination scenario, this limitation is not important except for evolution in the baseline; it would become more important if we were looking at partial elimination of export taxes. Similarly, import duties are also defined exogenously and do not react endogenously to changes in export taxes. ${ }^{8}$ This simplifying assumption is necessary in order to make the model tractable, though it should be kept in mind that in reality, the imposition of an import tariff or export tax by one country may lead to the further imposition of retaliatory tariffs and export restrictions in other countries, thus creating a vicious circle of trade retaliation with negative impacts on global welfare.

Second, due to the important effect of export taxes on energy products, relying on the MIRAGE model's standard trade policy version may be a limitation. Indeed, both supply and demand of energy are based on the standard modeling approach (for example, no complementarity exists between capital and energy) rather than on the advanced features developed recently in the MIRAGE-Biof version of the model, which focuses on bioenergy (Valin, Dimaranan, and Bouët 2010). Because of limitation, supply and demand may overreact to a change in prices in the model. However, it is important to keep in mind that no current CGE accurately models the energy cartel and its price response behavior.

Third, we only focus on export taxes and not on export bans or export quotas. Bouët and Laborde (2011) adopted the same assumption. Although export quotas can be represented through an ad valorem equivalent, we do not have adequate information to calibrate such a parameter. More important, modeling the change in regime (binding/not binding) would prove difficult for several reasons. Concerning export bans, the CES-Armington framework would lead to an even more challenging issue, because we would need to calibrate latent demand. ${ }^{9}$ Finally, the differences in classification between the level of implementation for the quota/ban (products) and the sectoral nomenclature of the model would cause numerous technical difficulties. For this reason, we believe that quotas and bans would be more easily addressed in a partial equilibrium framework.

Fourth, the level of Armington elasticities plays an important role. These elasticities define the market power of a specific exporter since they indicate how captive the importer is vis-à-vis a specific supplier. The larger the elasticity, the lower the optimal export tax. When implementing the export tax elimination scenario, a large elasticity will boost the tax removal's trade creation effects. Therefore, we can be in a delicate situation - that is, combining a large Armington elasticity with initial large export taxes (such as the case of natural gas) can lead to very strong effects. In our central case, we use the standard GTAP Armington values, which have low values, and we perform a sensitivity analysis on this parameter using the values from World Bank's LINKAGE CGE model (van der Mensbrugghe 2005), which are higher and equal to double the standard GTAP elasticities.

\section{Experimental Design}

This section discusses the experimental design, including nomenclature and scenarios.

\section{Aggregation}

Tables A.1 and A.2 in the Appendix display the geographical (20 regions) and sectoral (28 sectors) nomenclatures of the experiment. For the purposes of our study, we have identified and disaggregated the most important value chains (oilseed and vegetable oils, forestry, lumber, and paper) and the most important trading countries/regions (Russia, Argentina, Western African countries, and China, among others).

\footnotetext{
${ }^{8}$ For a discussion, see Bouët and Laborde (2010).

${ }^{9}$ See Gohin and Laborde (2006) for a potential solution.
} 


\section{Scenario Design}

We run the model between 2004 (base year) and 2020. The baseline involves only one policy change: the multifiber agreements are phased out in 2004. No Doha Development Agenda (DDA) is implemented in the baseline (that is, no tariff reduction or export subsidy removal). In the baseline, capital is accumulated, labor supply follows on demographic projections, and total factor productivity is calibrated to reproduce the World Bank gross domestic production (GDP) projection up to 2020. Due to the relative scarcity of land and other natural resources, there is an upward price trend in the baseline. Agricultural prices go up between 10 and 20 percent in real terms during this period, as compared with the overall price index. Primary energy product prices go up between 40 and 60 percent during the same period.

With this baseline, we focus on one core policy scenario: the linear removal of all export taxes by all countries during 2010-2015. This scenario involves the elimination of all export taxes by both WTO and non-WTO countries. In the case of energy, this implies the removal of all barriers creating a price gap between domestic market prices and FOB exports, as the data for export taxes in this sector incorporate barriers other than export taxes. To measure the relative role of export restrictions in the most important sectors, we also simulate the elimination of export taxes on one type of activity at a time: extraction and energy, agriculture and agro-food, and other industrial goods (including forestry and leather). In addition, with the same model and dataset, we also simulate the removal of all import duties during the same period, as well as the elimination of both export and import taxes, in order to assign an order of magnitude to the role of export taxes in overall trade distortions. Finally, we perform a sensitivity analysis on the Armington elasticity value. Results are presented in section 3. 


\section{RESULTS}

We first analyze the results of an overall removal of export taxes for the world's key macro indicators. We then present results of a simultaneous removal of import tariffs and export duties. Finally, we show results from a sensitivity analysis on Armington elasticities.

\section{Global Effects}

The overall gain by the export tax removal represents 0.24 percent of global real income, or US $\$ 133$ billion per year by 2020 , and boosts world trade volumes by 2.8 percent compared with their 2020 level in the status quo. Large real income gains are concentrated as follows: +1.6 percent in oil-exporting countries, +0.2 percent in developed countries, and +0.1 percent in other developing countries.

Although core story is simple, these results must be examined carefully. In the country that applies export duties, removing export taxes boosts the production and exports of the affected sectors. Reducing distortions supports economic growth and income gains. Due to domestic competition for scarce production factors and real currency appreciation, other sectors contract, and imports rise, which may cause deindustrialization. ${ }^{10}$ However, increasing the supply of initially taxed exports reduces the world price of these products. When this last effect dominates the previous one, net losses can occur for some countries when their taxes are removed. In addition, a large country with high export taxes can flood the market and see larger efficiency gains, while also reducing the world price of the commodity it exports, thus creating pecuniary negative externalities for other exporting countries. Importing countries, on the other hand, can benefit from the decrease in international prices.

These mechanisms are reflected in our simulations, as shown in Table 2.5. Although some regions and countries that originally impose export taxes gain from tax removal (such as CIS bloc, West Africa countries, and North Africa countries), other taxing countries experience income losses (such as in the case of Argentina, South Asian countries, and oil exporters in Africa and Latin America). Due to the market power exhibited by many suppliers, the removal of export taxes does not greatly alter the pattern of trade, but it does alter the volume.

The largest winner remains the CIS block (whose real income increases by 3.5 percent), especially Russia because the elimination of its large export taxes on energy products allows the region to obtain a large world market share, crowding out other exporters and inducing a significant ( -5.8 percent) decline of world gas and oil prices. ${ }^{11}$ The Dutch disease effect remains limited in this case. The expansion of oil and gas extraction competes weakly for production factors (due to a low share of total employment and a relatively low share of capital in the CIS region). In addition, under our assumption of fixed current account, incremental exports allow incremental imports in our model closure, because income is being redistributed to consumers.

Other oil exporters are negatively hit: real income falls in oil exporters in Africa ( -2.07 percent), Middle East and North Africa ( -1.71 percent), and Latin America ( -1.14 percent). Energy importers, among them the EU, benefit thanks to a decrease in international prices of oil and gas. Net importers of primary products gain from the export tax removal due to positive terms of trade effects (import volume can increase more quickly than export volume), as well as from new market opportunities for their products (symmetry of the export tax and the import duty for their partners). This is the case in China and India, which both benefit from a global removal of export taxes. These two countries would gain both from the removal of their own export taxes and from the removal of other partners' export taxes (in particular on energy products) that limit their supply.

\footnotetext{
${ }^{10}$ This phenomenon is known as the Dutch disease effect, referring to the decline of the manufacturing sector of a country due to decreased competitiveness as a result of an appreciation of that country's currency, caused by inflow of revenues into a natural resource-intensive sector, as well as a shift of resources (such as labor) toward the natural resource-intensive sector.

${ }^{11}$ If we were to allow for strategic behavior, we could expect other oil exporters, by strategically reducing their production, to stabilize prices.
} 
Similar results are found in the wood market, though of a lesser magnitude. For example, West African countries expand exports of wood and gain from efficiency resource reallocation, whereas wood importers benefit from a fall in international prices.

Figure 3.1 shows the top international price reductions by sector occurring in 2020, as compared with the baseline. Therefore, these sectoral price reductions can only be explained by the removal of export taxes. Thus, the magnitude of these reductions must be related to the magnitude of export taxes by sectors. In energy (primary), in energy products (gas), in forestry (primary, wood), in oilseeds (soybeans and palm nuts), and in vegetable oils (soy oils and palm oil), the removal of high export taxes leads big exporters like Argentina (oilseeds and vegetable oils), CIS nations (energy and energy products), the MENA region (energy and energy products), and Eastern and Southern Africa (forestry products) to expand their exports. This significantly augments the world supply of these products, thus reducing world prices.

Figure 3.1-Top price reductions, world (FOB)

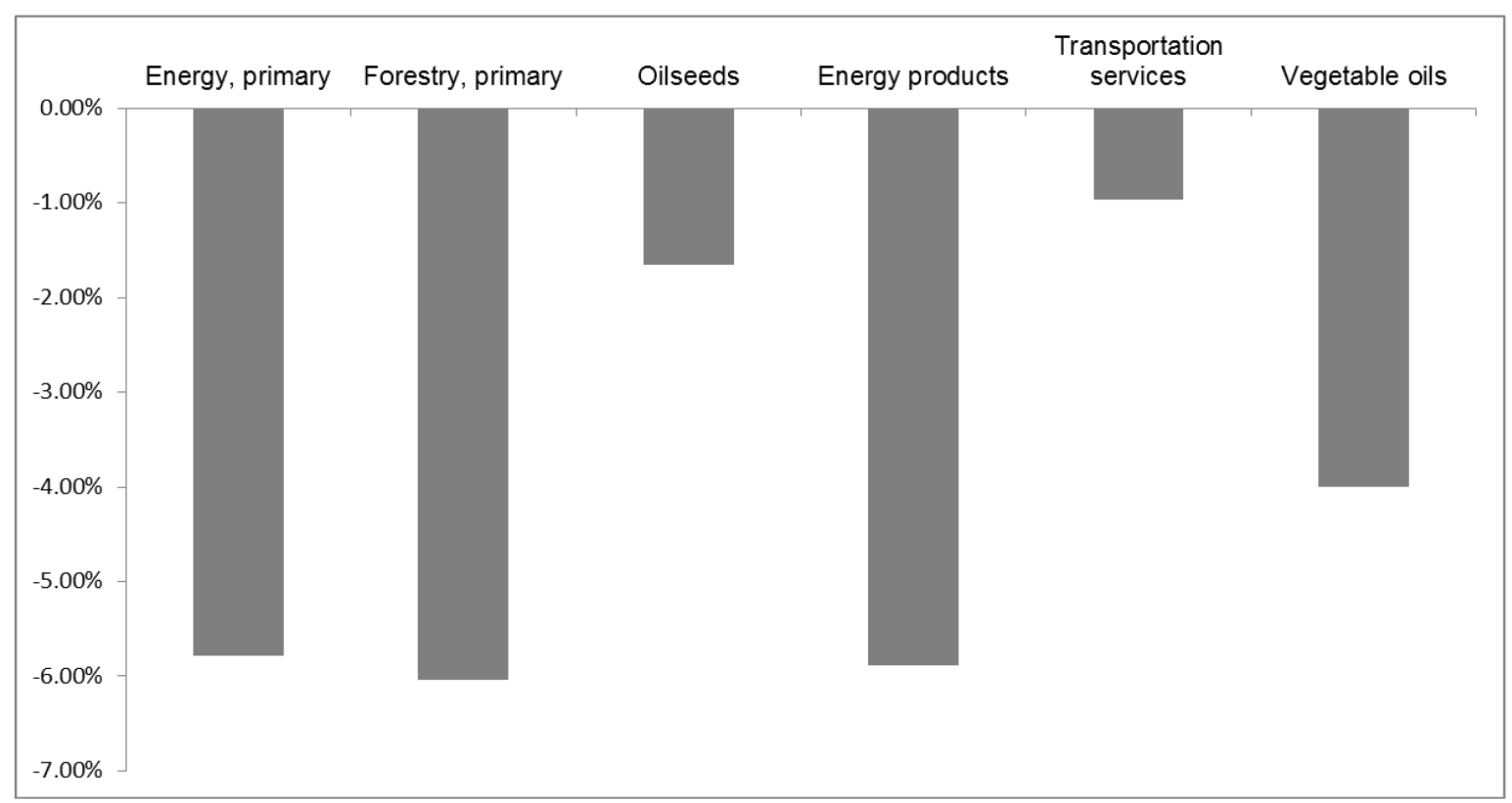

Source: MIRAGE simulations.

Table 3.1 shows the variation in national exports by country in 2020 due to the removal of export taxes. It confirms the previous analysis by pointing out a significant increase in exports in regions like Argentina, CIS and MENA regions, and Eastern and Southern Africa. 
Table 3.1-Global and regional effects of export tax removal, 2020

\begin{tabular}{|c|c|c|c|c|}
\hline Country / Zone & $\begin{array}{l}\text { Real Income } \\
\text { (percent) }\end{array}$ & $\begin{array}{l}\text { Imports } \\
\text { (percent, } \\
\text { volume) }\end{array}$ & $\begin{array}{l}\text { Exports } \\
\text { (percent, } \\
\text { volume) }\end{array}$ & $\begin{array}{l}\text { Government Net Changes } \\
\text { in Trade Tax Variations } \\
\text { (USD Millions) }\end{array}$ \\
\hline ANZCERTA & -0.06 & 0.56 & 1.21 & -972 \\
\hline Argentina & -0.20 & 8.16 & 8.00 & $-5,776$ \\
\hline ASEAN & -0.21 & 0.72 & 0.96 & $-4,537$ \\
\hline Developed East Asia & 0.21 & 0.72 & 0.10 & 192 \\
\hline Brazil & 0.03 & 1.09 & 0.92 & -153 \\
\hline China & 0.44 & 1.23 & 0.42 & -597 \\
\hline $\begin{array}{l}\text { Commonwealth of } \\
\text { Independent States }\end{array}$ & 3.52 & 45.46 & 45.72 & $-101,595$ \\
\hline $\begin{array}{l}\text { Eastern and } \\
\text { southern Africa }\end{array}$ & 0.66 & 5.01 & 4.24 & -213 \\
\hline EFTA & -1.10 & -1.09 & 0.85 & -192 \\
\hline European Union (27) & 0.41 & 1.90 & 0.79 & 230 \\
\hline Other Latin America & 0.10 & 0.02 & -0.16 & -379 \\
\hline MENA & 0.40 & 1.63 & 1.29 & -749 \\
\hline NAFTA & 0.09 & 0.44 & 0.09 & -126 \\
\hline Oil exporters Africa & -2.07 & -2.56 & 0.78 & -843 \\
\hline $\begin{array}{l}\text { Oil exporters Latin } \\
\text { America }\end{array}$ & -1.14 & -1.69 & 1.09 & -413 \\
\hline $\begin{array}{l}\text { Oil exporters MENA } \\
\text { region }\end{array}$ & -1.71 & 6.82 & 8.21 & $-2,517$ \\
\hline Rest of the world & -1.34 & -1.08 & 1.01 & $-1,881$ \\
\hline SACU & -0.21 & 0.12 & 0.80 & -856 \\
\hline South Asia & 0.51 & 1.71 & 0.96 & $-2,445$ \\
\hline Western Africa & 0.38 & 2.01 & 3.17 & $-1,419$ \\
\hline Developed countries & 0.21 & & & -868 \\
\hline Developing countries & 0.11 & & & $-19,010$ \\
\hline $\begin{array}{l}\text { Oil exporting } \\
\text { countries }\end{array}$ & 1.56 & & & $-105,370$ \\
\hline World & 0.24 & & 2.82 & $-125,248.90$ \\
\hline
\end{tabular}

Source: MIRAGE simulations.

Note: ANZCERTA: Australia-New Zealand Closer Economic Relations Trade Agreement; ASEAN: Association of Southeast Asian Nations; EFTA: European Free Trade Association; MENA: Middle East and North Africa; NAFTA: North American Free Trade Agreement; SACU: Southern African Customs Union.

The results in table 3.1 must be interpreted cautiously, because we look at the medium-term consequences of removing export taxes. Because oil and gas resources are of limited availability, the time management of these resources can be important. Therefore, the result of our simulation that shows large gains in the next 10 years due to increased exploitation of fossil resources by Russia should be interpreted in regards to decreased future flows of income, due to declining reserves, in the following decades. An intertemporal optimizing government may prefer to reduce production and national income now to protect future revenues, perhaps through a production tax or a production quota. 
Overall, we see that both developed countries and developing countries (that is, non-oil exporters) would benefit from removal of export duties. In some countries, there would be an erosion of terms of trade and a loss of direct government revenue (approximately US $\$ 5.7$ billion per year by 2020 for Argentina and about US\$100 billion per year by 2020 for CIS countries). However, important income reallocation would occur within these countries. For Argentina, the export tax removal would lead to large internal income redistribution, with land rents increasing by 56 percent.

Figure 3.2 shows income reallocation among the big sectors in oil-exporting countries, both developed and developing. Among developing countries, the agro-food, industry, and services sectors gain from an increase in value-added, whereas the "other primary" sector sees a decrease in its valueadded. Similar results, albeit with a higher impact on other primary value-added, are found in developed countries. Value-added for oil exporters increases in all sectors, though the highest gains are found in other primary sectors.

\section{Figure 3.2-Percentage changes in sectoral value-added by group of countries (in 2020 compared with the baseline)}

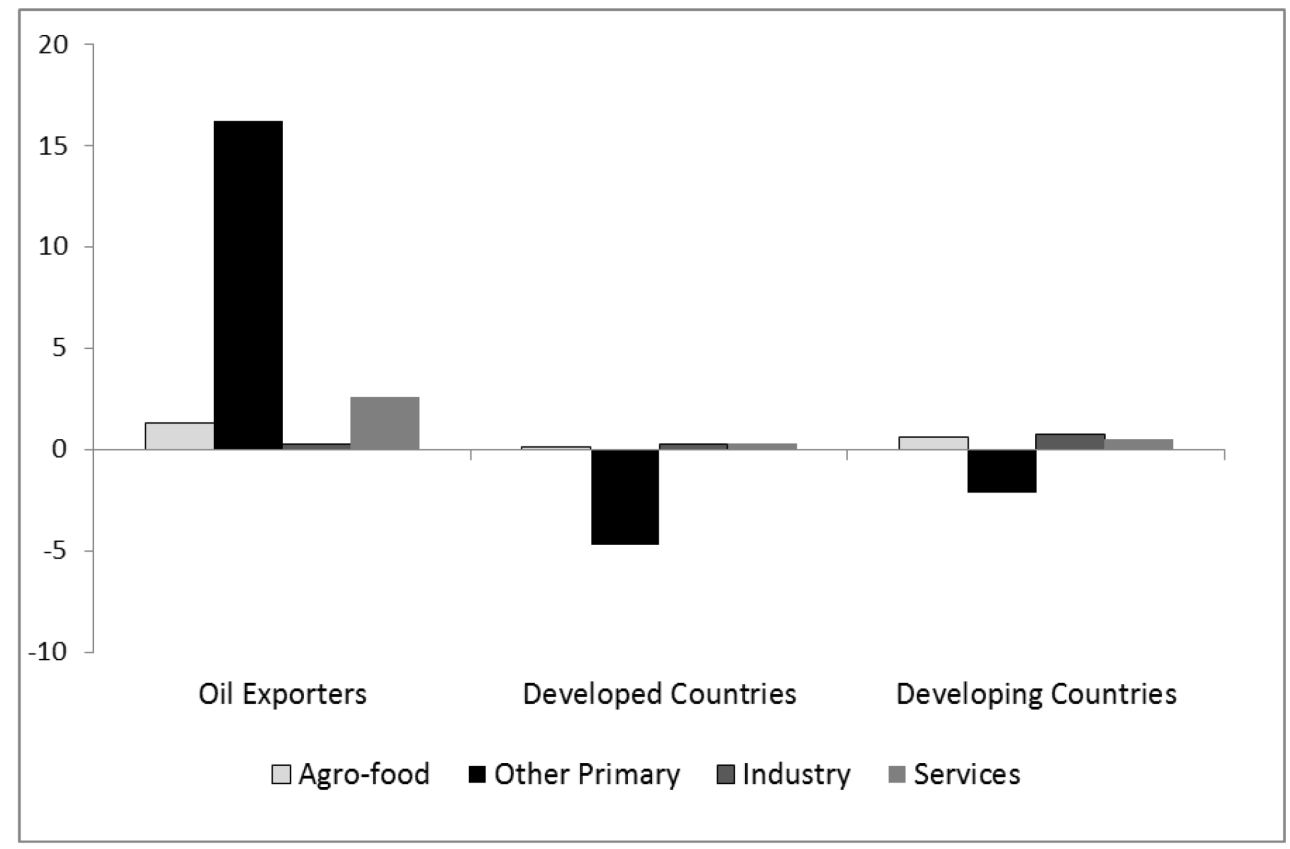

Source: MIRAGE simulations.

We have been considering the impact of a removal of all export taxes across the board, but it is also important to study the contribution of various activities to this larger picture. To do so, we use a decomposition technique designed by Laborde (2009) and used by Bouët and Laborde (2010) to compute normalized relative effects of the contribution of each sector.

In the case of real income (Figure 3.3), for most countries, the strongest effect is caused by the removal of export taxes on energy. Even for Argentina, which imposes large export taxes on agricultural sectors, the strongest effect on real income is generated by the removal of energy-sector export taxes. Like other oil-exporting countries, Argentina is significantly affected by the CIS bloc's expansion of energy exports. Interestingly, the removal of agricultural export taxes brings about a small increase in real income. The efficiency gains associated with the removal of the distortion effects outweighs the possible negative changes in terms of trade. 
Figure 3.3-Decomposition in the changes of real income by activity

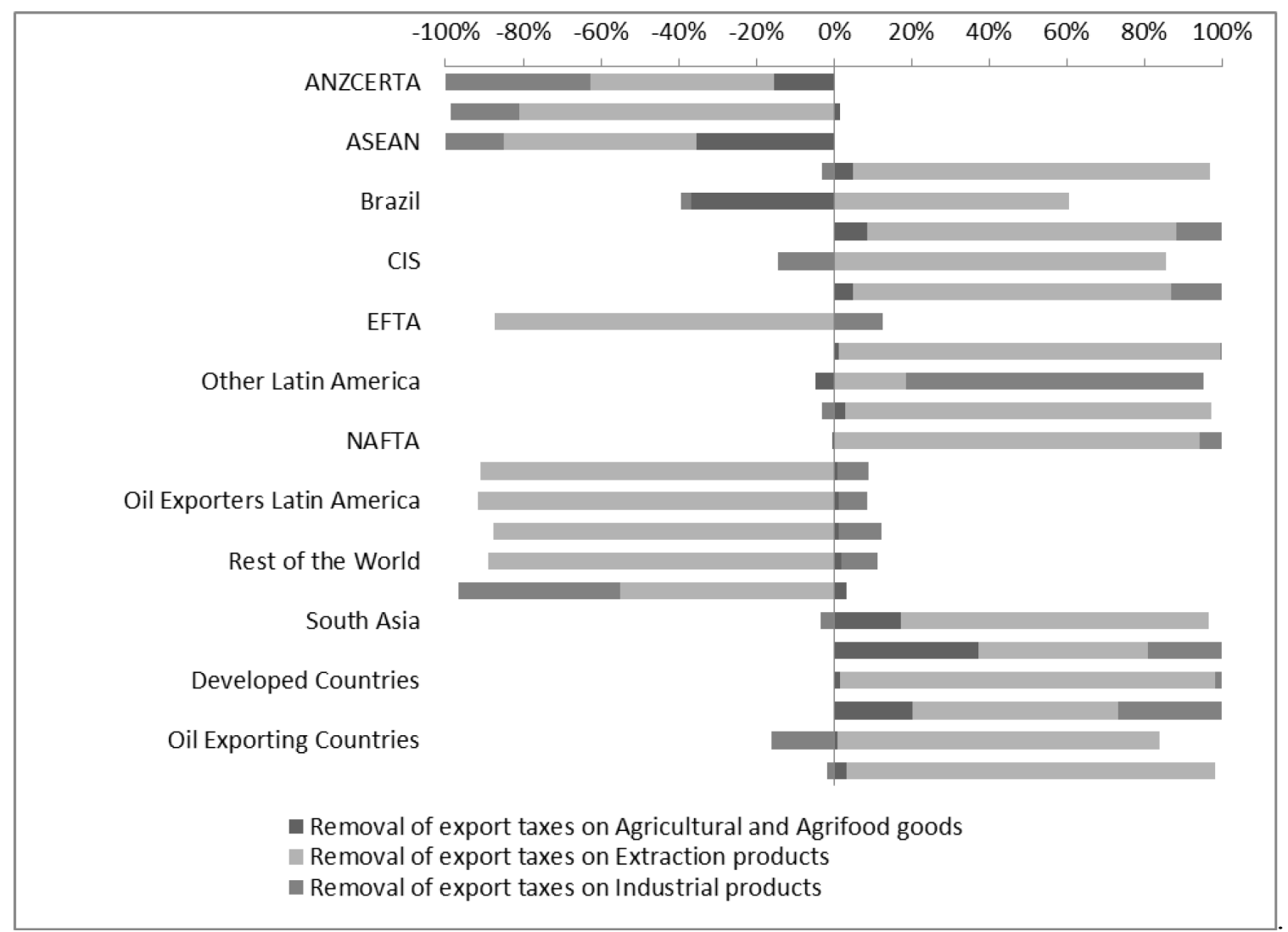

Source: MIRAGE simulations.

For China, the removal of export taxes on energy is also the main determinant of the real income increase, though in this case, the agricultural sector also plays an important role, determining more than 5 percentage points of total gains. West Africa and South Asia also gain from the removal of export taxes in the agricultural sector. This is because the food bill represents an important component of total imports (especially vegetable oil for South Asia), and agriculture prices decline as a result of the removal. In West Africa, export taxes on agriculture are also an important source of distortions, and the removal of these taxes would be positive for this region.

In the case of the European Union, the energy sector accounts for almost all of the gains, as the region benefits from the decrease in world oil prices. It is also worth mentioning the case of ASEAN, where all sectors contribute similarly to the fall in real income, as well as the case of Brazil, which is one of the main losers from the removal of agriculture export taxes. Because Brazil does not apply export taxes on agricultural products, it does not gain from efficiency gains and is harmed by the fall in agricultural prices worldwide.

The global increase in exports by volume is mainly driven by the removal of export taxes on energy (Figure 3.4). Again, this sector accounts for most changes in exports in all regions, except Argentina, Western Africa, and ASEAN, where the elimination of taxes on agricultural products drives the increase in exports, and in MENA and China, where the industrial sector has the greatest effect on export variations. It is worth mentioning the case of other Latin American countries and, to a lower extent, the Southern African Customs Union (SACU), where exports fall significantly as a result of the elimination of export taxes on energy, due to increased competition from other exporters initially applying export taxes. 
Figure 3.4-Decomposition in the changes of export volume by activity

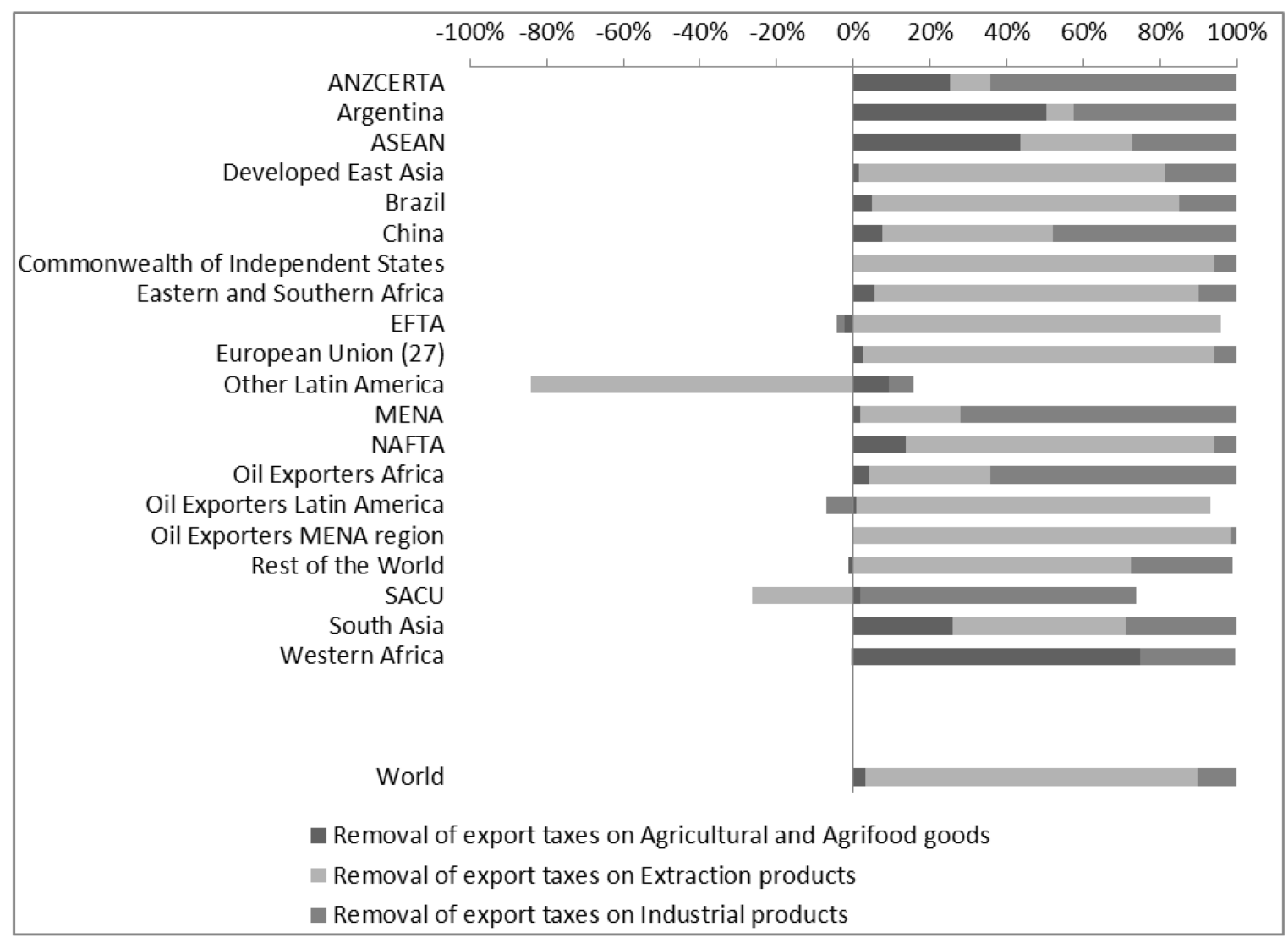

Source: MIRAGE simulations.

In most countries, government revenue from trade taxes decreases (see Figure 3.5). It should be kept in mind that the effect of export tax removal on government revenue is twofold: on the one hand, revenue falls in the country originally applying export taxes, as the government no longer collects these taxes; on the other hand, however, some countries increase tariff revenue as they increase imports of goods for which export taxes are removed in other countries. This latter effect may be eroded if the main tariff component is ad valorem; in this case, the removal of export taxes would lead to a fall in CIF prices, and thus import values may not increase substantially. For example, it is possible that the volume of imports of a certain good, such as oil, would increase substantially due to the removal of export taxes, but at the same time, the unit price of this good would fall due to increased world supply. Thus, even though the volume of imports might increase greatly, the total value of imports (price multiplied by quantity) might not, in which case the tariff revenue collected via an ad valorem tariff would also not be greatly affected.

The first effect is very clear in the case of Argentina and CIS countries, where the decrease in revenue is mainly explained by the sectors in which the regions apply higher export taxes. The second effect is clear in the case of countries where government revenue increases, such as in developed Asian countries and the European Union. In the case of the EU, government income increases because tariff revenues rise, as imports increase significantly when export taxes on the industrial and energy sectors are removed worldwide. ${ }^{12}$ However, the increased production of goods previously subject to export taxes

\footnotetext{
${ }^{12}$ Note that for many countries that apply numerous specific tariffs, such as the European Union, Japan, and Korea, the increase in volume imports will generate more revenue independent of the decrease in CIF prices. This effect is not captured here, because all tariffs are modeled as ad valorem equivalent.
} 
could constitute an opportunity for extending the tax base and preserving government revenues. Indeed, trade tax revenues (displayed in Figure 3.5) are only a fraction of government income that is aimed to decline with economic growth and diversification.

Figure 3.5-Decomposition in the changes of government income from trade taxes, by activity

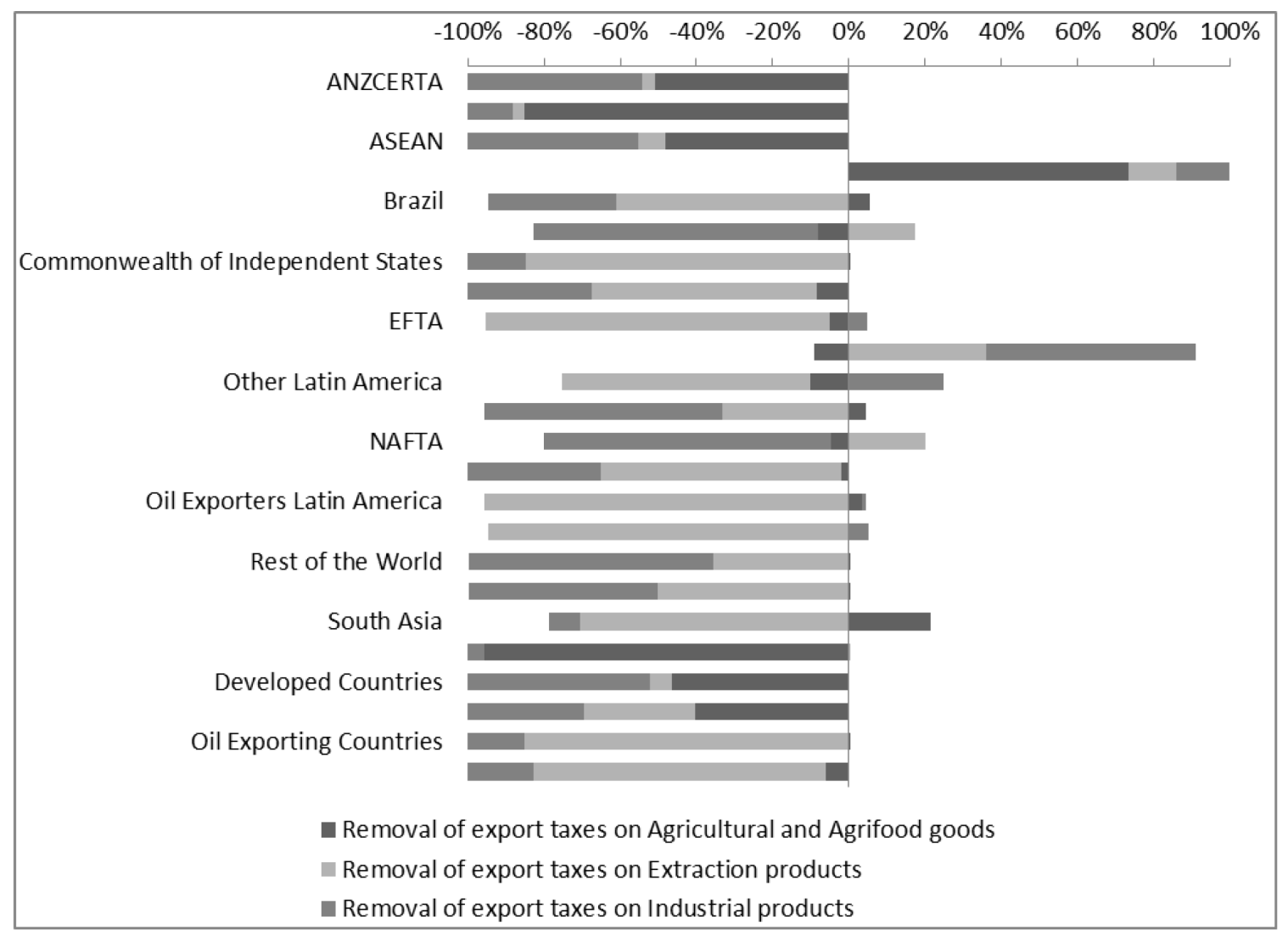

Source: MIRAGE simulations.

Table 3.2 shows the evolution of world trade, excluding intra-EU trade, following the removal of export taxes. As expected, the most heavily affected sectors are those with larger initial export taxes: gas, coal, and oil ( +21.7 percent); vegetable oils $(+14.7$ percent); forestry products (raw at +13.8 percent or processed at +3.6 percent); leather products $(+2.6$ percent); and cocoa and coffee (included in other crops, +2.9 percent). World production is also redistributed, and trade in processed commodities increases due to improved international division of labor in the value chain. For example, trade in refined energy products increases by 8 percent. At the same time, due to resource reallocation, some traditional exporters change their production mix. For instance, oilseeds production replaces cereals production in Argentina and Ukraine (CIS region). As noted earlier, main price changes on world markets are concentrated on energy products $(-5.8$ percent), as well as vegetable oils ( -4.0 percent $)$ and forestry products $(-6.2$ percent $)$. 
Table 3.2 - Changes in global trade: Sectoral results (in 2020 compared with the baseline)

\begin{tabular}{lrll}
\hline Cereals & 0.78 & Chemicals & 0.49 \\
Dairy products & 0.23 & Electronics & 0.05 \\
Fisheries & 0.55 & Energy products & 8.06 \\
Meat products & 2.29 & Leather products & 2.62 \\
Nonfood agricultural inputs & 0.17 & Metals & 0.65 \\
Oilseeds & 0.74 & Other industries & 0.42 \\
Other crops & 2.92 & Paper products & 0.28 \\
Other processed food & 0.50 & Textiles & 0.31 \\
Sugar & 1.01 & Transportation vehicles & 0.07 \\
Vegetables and fruits & 0.90 & Wearing apparel & 0.22 \\
Vegetal oils & 14.69 & Wood products & 3.63 \\
Energy, primary & 21.67 & Services & 0.16 \\
Forestry, primary & 13.89 & Transportation services & 0.38 \\
Mineral, primary & 0.96 & Trade & -0.34 \\
Mineral products & 0.54 & & \\
\hline
\end{tabular}

Source: MIRAGE simulations.

\section{Relative Importance of Export Taxes Compared with Import Duties}

Comparing the effects of export tax removal with tariff liberalization, which has been more widely studied, offers helpful insights. Figure 3.6 displays the results of three scenarios: the removal of all export taxes, the removal of all import duties, and the removal of both. We present results on global real income and imports for each scenario.

It appears that even if they are, on average, much less frequent and of lower magnitude than import duties (the average ad valorem equivalent of export taxes is only one-tenth the average ad valorem equivalent for import duties), export taxes still have a high real income cost - more than half that of import duties. On the other hand, their effects on trade are more limited (equal to one-sixth the effect for import duties), largely due to the nature of the energy sector, which is most affected by export taxes. These restrictions hinder the growth of all sectors in most of the consuming economies that do not have the capacity to produce substitutes for energy products. 


\section{Figure 3.6-Comparing elimination of tariff export restrictions and import restrictions}

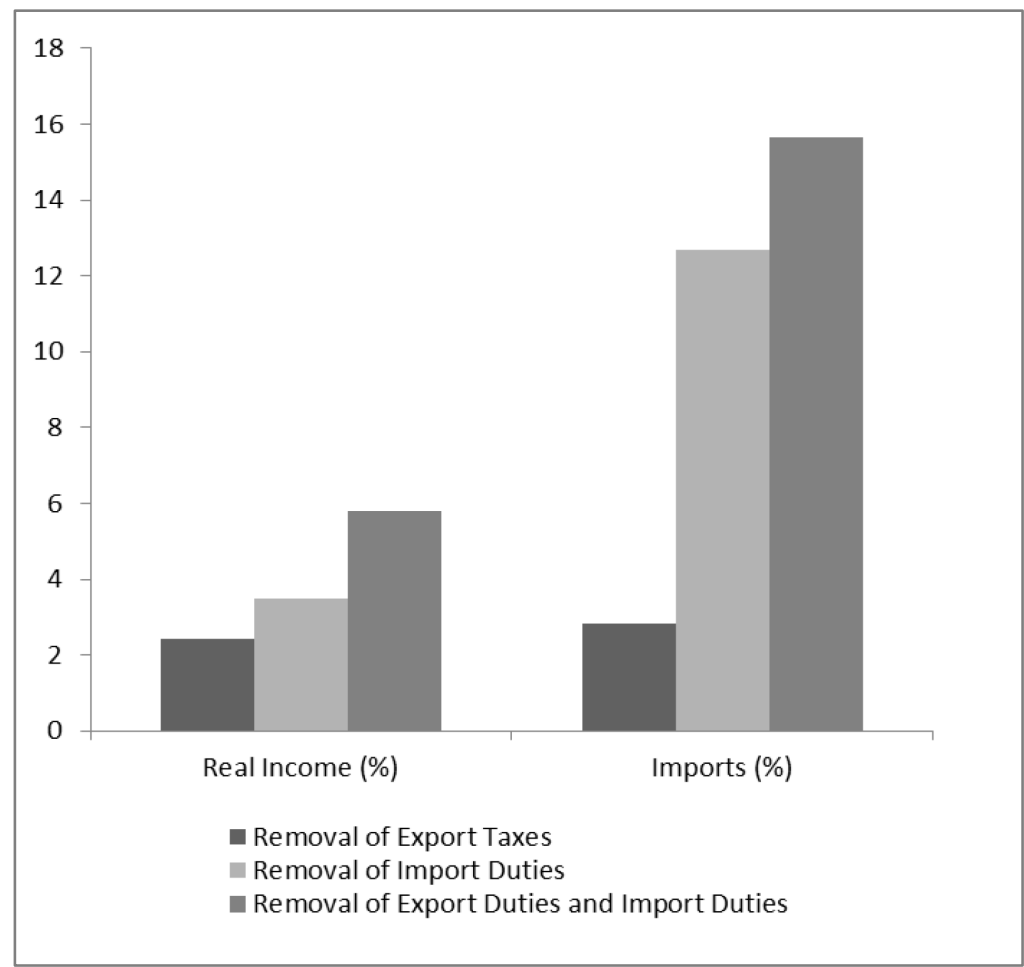

Source: MIRAGE simulations.

Note: Three scenarios are displayed in this graph: the complete elimination of export taxes by all countries in the world, the complete elimination of import duties by all countries in the world, and the combination of both scenarios.

\section{Sensitivity Analysis}

As presented above, assessing the sensitivity of our results to changes in the Armington elasticity values is important because results on exports can be significantly modified. To do such an assessment, we perform the same simulations using elasticities twice as large as our central case, which reflects a baseline scenario in which products from different countries are considered less differentiated than in the previous setup. In other words, with a higher Armington elasticity, a country is more willing to substitute products from different countries (or, equivalently, products from two different countries are considered more homogeneous than in the previous scenario). With higher Armington elasticities, changes in world prices caused by the elimination of taxes will have larger effects on trade patterns, because countries are now more willing to substitute goods from other countries. Results are displayed in Table 2.3.

As shown in Table 3.3, the overall results are multiplied by 1.5, with a real income increase of 0.33 percent at the world level (instead of 0.24 percent) and a rate of increase of global trade of 3.87 percent. However, these changes are not homogenous. Some countries are particularly affected. Oil exporters - in particular, in the MENA region-benefit more from the reform. Trade creation dominates trade deviation - that is, for these exporters, the expansion of sales to foreign counties is now enough to overcome the fall in world price of their exports, which results from the increased supply, as well as any increased competition from other suppliers, whose price drops even more due to the removal of their export taxes. This effect is natural for large Armington elasticities in the two-level nested approaches we use in our CGE, where trade deviation dominates trade creation when changing relative competitive positions among exporters. 
The situation of Argentina improves in this scenario, mainly because the trade deviation/price competition driven by the removal of export taxes in ASEAN countries on palm oil is stronger. Indeed, because both soybean oil and palm oil are merged under the vegetable oil sector, we implicitly assume that in the model, the level of substitution between both types of oils is given by the Armington elasticity. This is because we have a natural matching between feedstock used by the crushing industry and the country of origin of the vegetable oil. The ASEAN region faces a different outcome, because the regional oil producers benefit from the trend in oil markets described above.

The European Union is an example of a region in which high Armington elasticities have a major effect. A high elasticity on energy products from CIS countries leads to an explosion of imports. The volume effects dominate the price effect, and the current account constraint forces the European Union to a strong real exchange rate depreciation, thus actually impoverishing the region.

Table 3.3 - Sensitivity analysis on global and regional effects of export tax removal on real income and export volume

\begin{tabular}{lrrrr}
\hline & \multicolumn{2}{c}{ Real Income (percent) } & \multicolumn{2}{c}{ Export Volume (percent) } \\
& Central & High & Central & $\begin{array}{c}\text { High } \\
\text { Value }\end{array}$ \\
& Armington & Value & Armington \\
\hline ANZCERTA & -0.1 & -0.1 & 1.2 & 3.2 \\
Argentina & -0.2 & 0.1 & 8.0 & 14.6 \\
ASEAN & -0.2 & -0.1 & 1.0 & 1.9 \\
Developed East Asia & 0.2 & 0.3 & 0.1 & 0.2 \\
Brazil & 0.0 & 0.1 & 0.9 & 1.6 \\
China & 0.4 & 0.6 & 0.4 & 0.7 \\
Commonwealth of Independent States & 3.5 & 6.0 & 45.7 & 54.0 \\
Eastern and Southern Africa & 0.7 & 1.7 & 4.2 & 6.2 \\
EFTA & -1.1 & -1.0 & 0.9 & 0.8 \\
European Union (27) & 0.4 & 0.4 & 0.8 & 1.1 \\
Other Latin America & 0.1 & 0.3 & -0.2 & 0.0 \\
MENA & 0.4 & 0.6 & 1.3 & 3.6 \\
NAFTA & 0.1 & 0.1 & 0.1 & 0.2 \\
Oil exporters, Africa & -2.1 & -2.6 & 0.9 & 1.7 \\
Oil exporters, Latin America & -1.1 & -1.4 & 1.1 & 1.0 \\
Oil exporters, MENA region & -1.7 & -1.1 & 8.2 & 39.1 \\
Rest of the world & -1.3 & -1.7 & 1.0 & 1.7 \\
SACU & -0.2 & -0.2 & 0.8 & 1.7 \\
South Asia & 0.5 & 0.8 & 1.0 & 1.8 \\
Western Africa & 0.4 & 0.6 & 3.2 & 4.7 \\
World & 0.2 & 0.3 & 2.8 & 4.1 \\
\hline Souce: MIRAGE & & & &
\end{tabular}

Source: MIRAGE simulations. 


\section{CONCLUDING REMARKS}

Export taxes, a subset of export restrictions, are applied widely throughout the world - mostly in the energy sector, but also in the agricultural sector. Their effect on world trade and welfare, however, has not been widely studied, partly because of information constraints. To overcome this problem, we have built a database at the HS6 level for all countries in the world. Even though this database still has some limitations (for example, it does not include bilateral information), it is the most comprehensive database on export taxes to date.

On average, export taxes applied in the world are 0.48 percent of total trade. These export taxes are highly concentrated in the energy sectors (natural gas, petroleum, and coal), raw agricultural products (raw hides, oilseeds, cotton, and cocoa), minerals, processed oilseeds (soybean oil and palm oil), aluminum and iron (scraps and semiprocessed), and timber (rough and logs). We simulate the complete removal of all export taxes within a general equilibrium framework applying MIRAGE.

From a global point of view, export taxation represents a significant distortion. The overall gain from the removal of all export taxes would amount to a 0.24 percent increase of global real income (or US $\$ 33$ billion per year) by 2020. World trade volumes would increase by 2.7 percent. Extending the analysis to other types of export restrictions would only strengthen this conclusion.

From a policy standpoint, we have shown that the export tax issue should be a topic of interest for global policymakers, because it will generate gains equal to two-thirds of those associated with the complete elimination of import duties and more than the expected gains of the Doha Round. Both developed and emerging economies, such as China and India, would gain from such policies, even if they currently impose export taxes. Medium and small food-importing countries without market power (such as the least-developed countries) would also benefit from the elimination of export restrictions, especially during food crisis situations.

Both the energy sector and the export taxes implemented by the CIS countries appear to play a critical role in the overall economic impact of such a policy change. However, the fact that some countries (such as Argentina) would experience income losses is a major challenge to an overall positive reform in this area.

These results have one important caveat: Due to the intrasectoral aspect of some export taxes, large sectors - such as the car industry in the GTAP sector - do not allow us to capture the value-added support structure of export taxes. Because export taxes are aggregated to the GTAP sectoral level, in some sectors that exhibit reverse tax escalation, the information is lost, and all goods in the sector appear with the same export tax. Therefore, some variations of the model, such as allowing for a more disaggregated tariff structure (see Corong, Dimaranan, and Laborde [2009], where this issue is addressed for import duties), would be ideal. However, such a change would require significant data and modeling efforts. 


\section{APPENDIX: SUPPLEMENTARY TABLES}

Table A.1-Geographical aggregation and GTAP correspondence

\begin{tabular}{lll}
\hline Region Code & Region Label & GTAP Regions (GTAP 7.1 code) \\
\hline ANZCERTA & ANZCERTA & AUS, NZL \\
RoW & Rest of the world & XOC, ALB, HRV, XWS \\
CHINA & China & CHN, HKG \\
ASIARICH & Developed East Asia & JPN, KOR, TWN, XEA, SGP \\
ASEAN & ASEAN & KHM, IDN, LAO, MYS, PHL, THA, VNM, XSE \\
SAFTA & South Asia & BGD, IND, PAK, LKA, XSA \\
NAFTA & NAFTA & CAN, USA, MEX, XNA \\
ARGENTINA & Argentina & ARG \\
OILLAC & Oil exporters Latin & BOL, ECU, URY, VEN, XSM \\
& America & \\
BRAZIL & Brazil & BRA \\
LAC & Other Latin America & CHL, COL, PRY, PER, CRI, GTM, NIC, PAN, XCA, XCB \\
EU27 & European Union (27) & AUT, BEL, CYP, CZE, DNK, EST, FIN, FRA, DEU, GRC, \\
& & HUN, IRL, ITA, LVA, LTU, LUX, MLT, NLD, POL, PRT, \\
EFTA & SVK, SVN, ESP, SWE, GBR, BGR, ROU \\
CIS & EFTA & CHE, NOR, XEF \\
OILMENA & Commonwealth of & BLR, RUS, UKR, XEE, XER, KAZ, KGZ, XSU, ARM, AZE, \\
MENA & Independent States & GEO \\
OILAFRICA & Oil exporters MENA & IRN, XNF \\
WAF & region & \\
EAFR & MENA & TUR, EGY, MAR, TUN \\
SACU & Oil exporters Africa & NGA, XCF, XAC \\
\hline & Western Africa & SEN, XWF \\
& Eastern and Southern & ETH, MDG, MWI, MUS, MOZ, TZA, UGA, ZMB, ZWE, \\
& Africa & XEC \\
SACU & BWA, ZAF, XSC \\
& &
\end{tabular}

Source: Model nomenclature. 
Table A.2-Sectoral aggregation and GTAP correspondence

\begin{tabular}{|c|c|c|}
\hline Sector Code & Sector Label & GTAP Sectors (GTAP 7.1 code) \\
\hline CEREAL & Cereals & PDR, WHT, GRO, PCR \\
\hline$V_{-} F$ & $\begin{array}{l}\text { Vegetables and } \\
\text { fruits }\end{array}$ & $V_{-} F$ \\
\hline OSD & Oilseeds & OSD \\
\hline SGR & Sugar & C_B, SGR \\
\hline MAT & $\begin{array}{l}\text { Nonfood agricultural } \\
\text { Inputs }\end{array}$ & PFB, WOL \\
\hline OCR & Other crops & OCR \\
\hline ANI & Meat products & CTL, OAP, CMT, OMT \\
\hline MILK & Dairy products & RMK, MIL \\
\hline FORESTRY & Forestry, primary & FRS \\
\hline FISH & Fisheries & $\mathrm{FSH}$ \\
\hline COG & Energy, primary & COA, OIL, GAS \\
\hline MIN & Mineral, primary & OMN \\
\hline VOL & Vegetable oils & VOL \\
\hline OFD & $\begin{array}{l}\text { Other processed } \\
\text { food }\end{array}$ & OFD, B_T \\
\hline TEX & Textiles & TEX \\
\hline WAP & Wearing apparel & WAP \\
\hline LEA & Leather products & LEA \\
\hline LUM & Wood products & LUM \\
\hline PPP & Paper products & PPP \\
\hline P_C & Energy products & P_C \\
\hline CRP & Chemicals & CRP \\
\hline NMM & Mineral products & NMM \\
\hline METALS & Metals & I_S, NFM, FMP \\
\hline AUTO & $\begin{array}{l}\text { Transportation } \\
\text { vehicles }\end{array}$ & MVH, OTN \\
\hline ELE & Electronics & ELE \\
\hline MAN & Other industries & OME, OMF \\
\hline SER & Services & $\begin{array}{l}\text { ELY, GDT, WTR, CNS, CMN, OFI, ISR, OBS, } \\
\text { ROS, OSG, DWE }\end{array}$ \\
\hline TRA & Trade & TRD \\
\hline TRANS & $\begin{array}{l}\text { Transportation } \\
\text { services }\end{array}$ & OTP, WTP, ATP \\
\hline
\end{tabular}

Source: Model nomenclature. 


\section{REFERENCES}

Anderson, K., and W. Martin. 2011. Export Restrictions and Price Insulation During Commodity Price Booms. World Bank Policy Research Working Paper 5645. Washington DC: The World Bank.

Bchir, H., Y. Decreux, J.-L. Guerin, and S. Jean. 2002. MIRAGE, a Computable General Equilibrium Model for Trade Policy Analysis. CEPII Working Paper. Paris: Centre d'Etudes Prospectives et d'Informations Internationales.

Bouet, A., and D. Laborde. 2010. “Assessing the Potential Cost of a Failed Doha,” World Trade Review 9:319-351. . 2011. "Food Crisis and Export Taxation: The Cost of Non-Cooperative Trade Policies," Review of World Economics 148 (1): 209-233.

Boumellassa, H., D. Laborde, and C. Mitaritonna. 2009. A Consistent Picture of the Protection across the World in 2004: Macmaphs6 Version 2. IFPRI Discussion Paper. Washington, DC: International Food Policy Research Institute.

Corong, E., B. Dimaranan, and D. Laborde. 2009. Does Intra-Sector Tariff Heterogeneity Matter? GTAP Resource Paper no. 2982. West Lafayette, IN: Center for Global Trade Analysis, Purdue University.

Crosby, D. 2008. "WTO Legal Status and Evolving Practice of Export Taxes." Bridges 12 (5): 3-4.

Decreux, Y., and H. Valin. 2007. MIRAGE, Updated Version of the Model for Trade Policy Analysis: Focus on Agriculture and Dynamics. CEPII Working Paper 15. Paris: Centre d'Etudes Prospectives et d'Informations Internationales.

Gohin, A., and D. Laborde. 2006. "Simulating Trade Policy Reforms at the Detailed Level: Some Practical Solutions." Paper presented at the Ninth Annual Conference on Global Economic Analysis, Addis Ababa, Ethiopia, June 15-17.

Laborde, D. 2009. "Decomposition of Multilateral Trade Policy Shocks in a CGE." Mimeo. International Food Policy Research Institute, Washington, DC.

Narayanan, B. G., and T. L. Walmsley, eds. 2008. Global Trade, Assistance, and Production: The GTAP 7 Database. West Lafayette, IN: Center for Global Trade Analysis, Purdue University.

Piermartini, R. 2004. The Role of Export Taxes in the Field of Primary Commodities. WTO Discussion Paper. Geneva: World Trade Organization.

Turner, J. A., J. Buongiorno, A. Katz, and S. Zhu. 2008. "Implications of the Russian Roundwood Export Tax for the Russian and Global Wood Products Sectors." Scandinavian Journal of Forest Research 23 (2): 154166.

Valin, H., B. Dimaranan, and A. Bouët. 2010. "Evaluating the Environmental Cost of Biofuels Policy: An Illustration with Bioethanol.” International Economics 122:57-88.

Van der Mensbrugghe, D., 2005, LINKAGE Technical Reference Document Version 6.0., siteresources.worldbank.org/INTPROSPECTS/Resources/334934-1100792545130/LinkageTechNote.pdf

Warr, P. 2001. "Welfare Effects of an Export Tax: Thailand's Rice Premium." American Journal of Agricultural Economics 83 (4): 903-920. 


\section{RECENT IFPRI DISCUSSION PAPERS}

\section{For earlier discussion papers, please go to www.ifpri.org/pubs/pubs.htm\#dp. All discussion papers can be downloaded free of charge.}

1240. The Women's Empowerment in Agriculture Index. Sabina Alkire, Ruth Meinzen-Dick, Amber Peterman, Agnes R. Quisumbing, Greg Seymour, and Ana Vaz, 2012.

1239. Food price volatility in Africa: Has it really increased? Nicholas Minot, 2012.

1238. The comprehensive Africa agriculture program as a collective institution. Shashidhara Kolavalli, Regina Birner, and Kathleen Flaherty, 2012.

1237. Mechanization in Ghana: Searching for sustainable service supply models. Xinshen Diao, Frances Cossar, Nazaire Houssou, Shashidhara Kolavalli, Kipo Jimah, and Patrick Aboagye, 2012.

1236. Differential export taxes along the oilseeds value chain: A partial equilibrium analysis. Antoine Bouët, Carmen Estrades, and David Laborde, 2012.

1235. The role of rural producer organizations for agricultural service provision in fragile states. Catherine Ragasa and Jennifer Golan, 2012.

1234. Cash, food, or vouchers?: Evidence from a randomized experiment in Northern Ecuador. Melissa Hidrobo, John Hoddinott, Amber Peterman, Amy Margolies, and Vanessa Moreira, 2012.

1233. Public expenditures, private incentives, and technology adoption: The economics of hybrid rice in South Asia. David J. Spielman, Deepthi Kolady, Patrick Ward, Harun-Ar-Rashid, and Kajal Gulati, 2012.

1232. Malaria and Agriculture: A global review of the literature with a focus on the application of integrated pest and vector management in East Africa and Uganda. Benjamin Wielgosz, Margaret Mangheni, Daniel Tsegai, and Claudia Ringler, 2012.

1231. Did using input vouchers improve the distribution of subsidized fertilizer in Nigeria?:The case of Kano and Taraba states. Lenis Saweda O. Liverpool-Tasie, 2012.

1230. The supply of inorganic fertilizers to smallholder farmers in Tanzania: Evidence for fertilizer policy development. Todd Benson, Stephen L. Kirama, and Onesmo Selejio, 2012.

1229. The supply of inorganic fertilizers to smallholder farmers in Mozambique: Evidence for fertilizer policy development. Todd Benson, Benedito Cunguara, and Tewodaj Mogues, 2012.

1228. The supply of inorganic fertilizers to smallholder farmers in Uganda: Evidence for fertilizer policy development. Todd Benson, Patrick Lubega, Stephen Bayite-Kasule, Tewodaj Mogues, and Julian Nyachwo, 2012.

1227. Taxation policy and gender employment in the Middle East and north Africa region: A Comparative analysis of Algeria, Egypt, Morocco, and Tunisia. Ismaël Fofana, Erwin Corong, Rim Chatti, Sami Bibi, and Omar Bouazouni, 2012.

1226. Policy reform toward gender equality in Ethiopia: Little by little the egg begins to walk. Neha Kumar and Agnes R. Quisumbing, 2012.

1225. Improving the Measurement of food security. Derek Headey and Olivier Ecker, 2012.

1224. Improved performance of agriculture in Africa south of the Sahara: Taking off or bouncing back. Alejandro Nin-Pratt, Michael Johnson, and Bingxin Yu, 2012.

1223. Review of input and output policies for cereals production in Pakistan. Abdul Salam, 2012.

1222. Supply and demand for cereals in Pakistan, 2010-2030. Hina Nazli, Syed Hamza Haider, and Asjad Tariq, 2012.

1221. The road to specialization in agricultural production: Evidence from Rural China. Yu Qin and Xiaobo Zhang, 2012.

1220. Change and diversity in smallholder rice-fish systems: Recent evidence from Bangladesh. Madan M. Dey, David J. Spielman, A.B.M. Mahfuzul Haque, Md. Saidur Rahman, and Rowena A. Valmonte-Santos, 2012.

1219. Is MERCOSUR's external agenda pro-poor?: An assessment of the European Union-MERCOSUR free-trade agreement on poverty in Uruguay applying MIRAGE. Carmen Estrades, 2012.

1218. Heterogeneous pro-poor targeting in India's Mahatma Gandhi national rural employment guarantee scheme. Yanyan Liu and Christopher B. Barrett, 2012. 


\section{INTERNATIONAL FOOD POLICY}

RESEARCH INSTITUTE

www.ifpri.org

IFPRI HEADQUARTERS

2033 K Street, NW

Washington, DC 20006-1002 USA

Tel.: +1-202-862-5600

Fax: +1-202-467-4439

Email: ifpri@cgiar.org 